Kinestetik : Jurnal Ilmiah Pendidikan Jasmani 4 (2) (2020)

Kinestetik : Jurnal Ilmiah Pendidikan Jasmani

https://ejournal.unib.ac.id/index.php/kinestetik/index

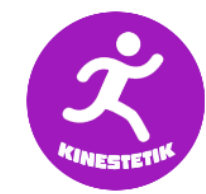

\title{
THE INFLUENCE OF LEARNING METHODS AND LEARNING MOTIVATION ON DISCS THROWING SKILLS (EXPERIMENTAL STUDY AT SMP NEGERI 24 MAKASSAR)
}

\author{
Suriah Hanafi ${ }^{1 *}$, Moch Asmawi ${ }^{2}$, Firmansyah Dlis ${ }^{3}$ \\ ${ }^{1}$ Department of Sport Education, Sport Science, Universitas Negeri Makassar, Indonesia \\ ${ }^{23}$ Pascasarjana, Sports Education, Universitas Negeri Jakarta, Indonesia
}

\section{Article Info}

Article History:

Received September 2020

Revised September 2020

Accepted September 2020

Available online September 2020

Keywords:

Learning methods, motivation, discus skills

\begin{abstract}
Aimfrom this research is to see the differences in three forms of learning methods, namely, the overall learning method, part learning method and mixed learning methods on the discus throwing skills of class IX students of SMP Negeri 24 Makassar who are members of the extra-curricular. The moderator variable in this study is learning motivation. The dependent variable is the discus throwing skill. This study used a $2 \times 3$ factorial experimental method, the population of this study was 134 students of SMP Negeri 24 Makassar. The determination of the sample size was based on purposive sampling technique by selecting $27 \%$ of the total data with the highest score and $27 \%$ of the lowest score referring to the Verducci theory. The conclusion from this research is that the group of students who are taught using the overall learning method has better results in discus throwing skills compared to the group of students who are taught disc-throwing skills using the part learning method and groups of students who are taught with mixed learning methods. For students who have high motivation, the learning method using the overall method is better used in teaching discthrowing skills, for students with low motivation categories the mixed learning method is better used in teaching disc throwing skills than using the whole learning method and the part learning method in improving disc throwing skills
\end{abstract}

Corresponding address: Kelapa Dua Resident Blok E11

Depok, West Java

Email
ISSN 2685-6514 (online)

ISSN 2477-331X (print)

DOI : $10.33369 / j k . v 4 i 2.12515$ 


\section{INTRODUCTION}

Physical education is an educational process that is carried out consciously and systematically through various physical activities in order to acquire physical abilities and skills, physical changes and character growth.

Physical activities referred to above are activities carried out by students to improve motor skills and abilities which include cognitive, affective and psychomotor aspects, so that physical education begins to be applied from an early age starting from kindergarten to college, because physical education is a medium. booster of motor skills, physical abilities, knowledge and reasoning as well as habituation to a healthy lifestyle(Slameto, Sulasmono, \& Wardani, 2017). The purpose of physical education is to support the achievement of the goals of national education. In addition, physical learning is not only physical learning and healthy lifestyles but there are elements of play and sports so it is necessary to have facilities and infrastructure that can support teaching and learning activities.

Physical education materials are part of the educational curriculum which functions to convey materials and the formation of characteristics ranging from discipline, honesty, fighting spirit, cooperation and sportsmanship. Physical education is education that teaches about motion to improve the fitness of each student so that in the learning process students can learn well.

Organizing teaching and learning activities for students is the teacher's job. To carry out effective teaching and learning activities, it takes knowledge of the nature of teaching and learning and teaching and learning strategies. Teaching and learning activities are a unity of two unidirectional activities. Learning activities are primary activities, while teaching activities are secondary activities that make learning activities optimal.

Teaching and learning activities are said to be optimal when there is interaction between students and teachers and / or learning materials in certain places that have been arranged in order to achieve goals. Teaching and learning situations can be optimized if the appropriate methods and / or media are used. To find out the effectiveness of teaching and learning activities, at the end of the lesson, evaluation should always be carried out.

There are many sports that are taught in physical education, athletics is one of them. Athletics is the parent of all existing sports, it is said that the parent of all existing sports is because every element of motion that is in athletic sports is the basis of all sports movements where there are elements of motion in the form of speed, strength, power. resistance, flexibility, and coordination,

Athletics is one of the sports that must be introduced to children from an early age, because it must be introduced from an early age so athletics is one of the subjects in physical education that is required in schools ranging from elementary, middle to high school levels. issuance of Minister of Education and Culture Decree No. 04135 / U / 1987 which regulates this.

From the results of the researchers' observations during the implementation of PLPG for Physical Education teachers which was held in Makassar, the researchers obtained information that athletic sports, especially the rotating style discus throwing numbers, are rarely taught 
because they are less attractive to students, students are more interested in sports such as soccer, basketball, volleyball, this is because in these sports the students play in groups, they feel bored with individual sports not to mention that the technique of throwing discs with a rotating style is quite complicated. Due to the lack of interest and motivation of the students towards the discus throwing material, the teacher became reluctant to teach it.

Creating a learning atmosphere that can motivate students to follow learning materials is a challenge for every teacher when teaching. Selection of the right learning method is one of the solutions, the use of appropriate learning methods with the material we teach can attract students' interest to be actively involved in the learning activities that we will carry out, besides the selection of learning media, a conducive school environment and other things. other things that can influence student interest. The choice of learning method that is applied can be different for each subject matter that we will present, or maybe this week we use learning method A next week we can replace it with learning method B, depending on the student's current position.

\section{Overall Learning Method}

Learning methodswhole is a way of teaching that focuses on the integrity of a movement skill that we teach, so the overall method requires students to carry out a complete set of motion techniques by not sorting out the movement part by part. Generally, the whole learning method is applied to a simple form of movement skills, as expressed by Harsono "If the sports skills being taught are simple and easy to understand, then these skills should be taught as a whole, and each part of the technique is only trained specifically if the student or subject always makes mistakes in a certain part of the technique"(Harsono, 2017). While(Fatah) revealed, "The overall method delivers the maximum benefit if what is learned is simple movements".

The implementation of the overall method of throwing the disc is by doing the technique of throwing the disc as a whole, starting from the initial position movement, swinging, rotating, to releasing the disc.

\section{Learning Methods Section}

The form of part learning method is a form of teaching movement skills which is carried out in part. According to Sugianto (1996: 67) "The part method is an approach where students are initially directed to practice part of the whole series of movements, and after the parts of the movement are mastered, then the parts of the movement are assembled into a single unit of throwing the disc.

\section{Mixed Learning Methods}

Shape Mixed learning method is a form of teaching method that combines two forms of learning methods, in this case combining the whole learning method and the part learning method. Forms of movement skills are taught starting from easy and simple movements in stages, then part by part of the movement is assembled into one part of the movement and finally assembled into one overall movement of the movement. the skills being taught. so there is a series of motion.Opinions of Warburton et al. (2008) stated (mixed method) that: The whole-part-whole practice model is an extension from both the whole and part practice methods. In the whole-partwhole model, the subject is provided with the skill in its entirety before having it broken down into parts and taught using 
the segmentation, simplification, or fractionization methods.

The definition is that the wholepart-whole learning model is also called the combination method or the whole method and the part method. In the whole-part-whole model, subjects are taught with overall skills and are broken down into sections and taught using segmentation, simplification, or practical methods

The Combination method, hereinafter referred to as the method, is a method that combines techniques / elements with whole / whole. In physical education teaching practices, this mixed teaching method is often used.

\section{Understanding Learning Motivation}

The term learning motivation that we know so far comes from the word motive which is also defined as the power or effort that encourages someone to do something. Motivation is the basic driving forcesomeone to do something or behave. According toMulyaningsih, (2014)Motivation is defined as a state that exists in a person that encourages him to carry out certain activities in order to achieve a goal.

\section{The Importance of Student Learning Motivation}

Motivation is an impetus that can move a person to learn, motivation to work is also a driving force for community progress. Motivation needs to be owned by students, the task of the teacher is how to generate motivation that is in students. In an international journal reveals that:

In our life motivation is base of any work because without motivation we cannot achieve anything. If the teacher motivate their students for any task, than they will achieve the goal.(Rehman \& Haider, 2013)

In our life motivation is the basis of any work because without motivation we cannot achieve anything. If the teacher motivates his students for any task, then they will achieve the goal.

The importance of generating student learning motivation because with this learning motivation has an important role in encouraging the spirit of desire students know to learn something. According to Hill et al in the journalAndrew P. Hill (2018) state that:

They also suggest that the influence of perfectionism is exceedingly complex. In one recent study, for example, international level athletes described perfectionism as a major source of their motivation, and instrumental to their sporting success

\section{Research methods.}

This research was conducted in order to see the difference, the learning method (A), namely the overall learning method (A1), the part learning method (A2) and the mixed learning method (A3) in teaching the discus throwing skills of class IX students of SMP Negeri 24 Makassar who joined in extra-curricular. The moderator variable of learning motivation (B) is in the form of high learning motivation (B1) and low learning motivation (B2) with the dependent variable throwing discs skills (Y) using the $2 \times 3$ factorial experimental method, the student population of SMP Negeri 24 Makassar is 134. Using purposive technique Sampling by selecting $27 \%$ of the total data with the highest score and $27 \%$ of the lowest score according to Verducci's theory.The research implementation process was 
carried out 3 meetings according to the schedule of physical education and health subjects at school, namely a week held 1 meeting for 2 times 45 minutes, each time at the end of the meeting an evaluation was carried out to see the progress of the learning implementation process.

\section{RESULTS AND DISCUSSION}

Test Requirements Analysis with Normality Test.

(1) Normality test for Learning Method Group (A)

The values of Lo A1, A2, and A3 are = $0.1362,0.058,0.0523$ with sample $=24$ and alpha 0.05 so that it is obtained $\mathrm{Lt}=$ 0.173 . The value of $\mathrm{L} 0<$ from $\mathrm{L}$ table, then group A is concluded to be normally distributed

(2) Normality Test Between Treatment Groups Learning Method (A) and Learning Motivation (B).

The results of the liliefors L0 normality test were $0.0097,0.1899,0.0857,0.0869$, $0.0797,0.0522$. The critical value of $\mathrm{LO}$ on the liliefors table for sample size $(\mathrm{n})=$ 12 with $\mathrm{a}=0.05$ from $\mathrm{L}$ table $=0.242$. The value of $\mathrm{L} 0<$ from $\mathrm{L}$ table, for the learning method group (A) and Learning Motivation (B) have normally distributed data.

Homogeneity Test.

(1) Homogeneity Test for Learning Method Groups (A).

The difference between Fcount and Ftable in these two groups has a homogeneous variant because the Fcount value $<$ from $F$ table $\alpha=0.05=2.00$ and $\alpha=0.01=2.70$

(3) Homogeneity Test Between

Treatment Groups A and B

When compared, Fcount and Ftable have differences so that the data between groups $\mathrm{A}$ and $\mathrm{B}$ are homegene as evidenced by the results of the Fcount $<$ from $\mathrm{F}$ table $\alpha=0.05=2.79$ and $\alpha=$ $0.01=4.40$ and accept H0.

Hypothesis testing

$\mathrm{F}$ count $=5,874 \mathrm{p}$-value $0.003<0.05$ has an average comparing the two groups, the proof is with R squer $0.890 \times 100=89 \%$

The difference in the average learning method of students who are taught using the A1, A2, and A3 methods as learning methods (A) has an effect on the discs' throwing ability (Y) in students.

(1) Hypothesis 1: Difference Between Group (A1) and Group (A2).

Hasisi analysis t0 (A1 X A2) $=13,498$ with sig. (2-tailed) $=0.002<0.05$, meaning that $\mathrm{HO}$ is rejected. Thus, the ability to throw discs (Y) in group A1 was higher than in group A2.

(2) Hypothesis 2: Difference Between Group (A1) and Group (A3).

In contrast (A1 $X$ A3) it can be analyzed that the price is $\mathrm{t} 0(\mathrm{~A} 1 \mathrm{X} \mathrm{A} 3)$ $=10,346$, sig. (2-tailed) $=0.002$ $<0.05, \mathrm{H} 0$ is rejected. The ability to throw discs in group A1 is higher than that of group A3.

(3) Hypothesis 3: Difference Between Group (A2) and Group (A3).

There is a contrast table (A2 X A3) that can be analyzed, namely the price of $\mathrm{t} 0(\mathrm{~A} 2 \mathrm{X}$ A3) $=11,892$, sig. (2tailed $)=0.006>0.05$, H0 is accepted. Thus, the ability to throw discs in group A2 is the same as in group A3

(4) Hypothesis 4: Interaction Effect

The results of the analysis show that the influence of group (A) and group (B) on $(\mathrm{Y})$ is RSquared $=0.790 \times 100=79 \%$ so that it has an influence on group $A$ and group $\mathrm{B}$. In addition, the value of Fo (AB) $=10,345$ with $p$-value $=0.000<0.05$ or 
$\mathrm{H} 0$ is rejected. This proves that there is a significant interaction between factor $\mathrm{A}$ (learning method) and factor B (learning motivation) to (Y).

(5) Hypothesis 5: The difference in ability outcomes (Y) between group A1 and group (B1) and group A2 with group B1 (A1B1 - A2B1).

The difference between groups t0 $(\mathrm{A} 1 \mathrm{~B} 1-\mathrm{A} 2 \mathrm{~B} 1)=4.052, \mathrm{p}$-value $=0.000$ / $2=0.000<0.05$ or $\mathrm{H} 0$ is rejected. The mean of group A1 is higher than group A2 for students in group B1.

(6) Hypothesis 6: Difference in skills (Y) between group A1 and group B1 and group B1 (A1B1 - A3B1).

The difference between groups t0 $(\mathrm{A} 1 \mathrm{~B} 1-\mathrm{A} 3 \mathrm{~B} 1)=2.132, \mathrm{p}$-value $=0.000$ / $2=0.000<0.05$ or $\mathrm{H} 0$ is rejected. The mean of group A1 is higher than group A3 for group B1 students

(7) Hypothesis 7: Difference in ability outcome (Y) between group A2 and group $\mathrm{B} 1$ and group $\mathrm{A} 3$ and $\mathrm{B} 1$ (A2B1 - A3B1).

The difference between groups t0 $(\mathrm{A} 2 \mathrm{~B} 1-\mathrm{A} 3 \mathrm{~B} 1)=4.001, \mathrm{p}$-value $=0.000$ / $2=0.000<0.05$ or $\mathrm{H} 0$ is rejected. The mean of group A2 was higher than group A3 for group B1.

(8) Hypothesis 8: The difference in results (Y) between group A1 and group B2 and group A2 with group B2 (A1B2 - A2B2).

The difference between groups $t 0$ $(\mathrm{A} 1 \mathrm{~B} 2-\mathrm{A} 2 \mathrm{~B} 2)=2.112, \mathrm{p}$-value $=0.822$ / $2=0.411>0.05$ or $\mathrm{H} 0$ is accepted. There was no difference in the average ability
(Y) between group A1 and group A2, for groups with B2.

(9) Ninth Hypothesis: The difference in ability outcomes (Y) between group $\mathrm{A} 1$ and group B2 and group A3 with group B2 (A1B2 - A3B2).

The difference between groups $t 0$ $(\mathrm{A} 1 \mathrm{~B} 2-\mathrm{A} 3 \mathrm{~B} 2)=2.081, \mathrm{p}$-value $=0.031$ $/ 2=0.0155<0.05$ or $\mathrm{H} 0$ is rejected. The average group A1 is lower than the A3 group, so that the B2 group is more suitable to use the A3 method

Hypothesis 10: The difference in ability outcomes (Y) between group A2 and group $\mathrm{B} 2$ and group $\mathrm{A} 3$ and group $\mathrm{B} 2$ (A2B2 - A3B2).

The difference between groups $\mathrm{t} 0$ (A2B2 - A3B2) $=2.021, \mathrm{p}$-value $=0.051 / 2=$ $0.0255<0.05$ or $\mathrm{H} 0$ is rejected. The mean of group A2 is lower than group A3 for group B2.

\section{CONCLUSION}

Based on the description in the above discussion, it is concluded that the overall learning method (A1) is better than the part learning method (A2) and the mixed learning method (A3). For students who have high motivation (B1), the learning method using the overall method (A1) is better at increasing the ability to throw discs (Y) than using the part method (A2) or using the mixed method (A3). For students with low motivation (B2) the mixed learning method (A3) is better at improving disc throwing skills (Y) than using the part method (A2) and the overall method (A1) in improving disc throwing skills (Y). 


\section{REFERENCES}

Asnaldi, A., Zulman, Z., \& Mardiah, M. (2018). Hubungan Motivasi Olahraga dan Kemampuan Motorik dengan Hasil Belajar Pendidikan Jasmani Olahraga dan Kesehatan Siswa Sekolah Dasar Negeri 16 Sintoga Kecamatan Sintuk Toboh Gadang Kabupaten Padang Pariaman. Jurnal Messana, 3(2), 16-27.

Amiluddin, R., \& Sugiman, S. (2016). Pengaruh problem posing dan PBL terhadap prestasi belajar, dan motivasi belajar mahasiswa pendidikan matematika. Jurnal Riset Pendidikan Matematika, 3(1), 100-108.

Andrew P. Hill, SHMH \& GEJ (2018). Research at the University of York St John. Perfectionism In Sport, 2857, 072. Retrieved fromhttps://psycnet.apa.org/doiLandin g?doi $=10.1037 / \mathrm{spy} 0000125$

Budiawan, M. (2013). Pengaruh model pembelajaran kooperatif tipe jigsaw dan motivasi belajar terhadap prestasi belajar ilmu fisiologi olahraga. JPI (Jurnal Pendidikan Indonesia), 2(1).

Ginanjar, A. (2015). Pengaruh Metode Inkuiri Terhadap Motivasi Belajar Siswa SMP. Jurnal Kependidikan, 45(2), 123-129.

Fatah, muhammad AN (2014). Journal of Physical Education, Sport, Health and Recreations. Journal of Physical Education, Sport, Health and Recreation, 4 (2), 1613-1620.

HARSONO, S. (2017). The Influence of the Demonstration Method on Learning Outcomes of Back Rolls (Study in Class Vii Â Smpn 2 Buduran Sidoarjo) Journal of Sports and Health Education, 6 (1), 25-29.

Manalu, W. (2017). Pengaruh Metode Pembelajaran dan Motivasi Belajar terhadap Hasil Belajar Lari Cepat. Jurnal Pendidikan Jasmani dan Olahraga, 2(2), 53-60.

Mulyaningsih, IE (2014). The Effect of Family Social Interaction, Learning Motivation, and Learning Independence on Learning Achievement. Journal of Education and Culture, 20 (4), 441. https://doi.org/10.24832/jpnk.v20i4.1 56.

Ramadan, G. (2017). Pengaruh metode pembelajaran dan motivasi belajar terhadap hasil belajar passing sepakbola. JUARA: Jurnal Olahraga, 2(1), 1-10.

Rehman, A., \& Haider, K. (2013). THE IMPACT OF MOTIVATION ON LEARNING OF SECONDARY SCHOOL STUDENTS IN KARACHI: AN ANALYTICAL STUDY, 2 (2), $139-147$.

Setiawan, A. (2017). Hubungan Authentic Assessment Dengan Motivasi Belajar Pendidikan Jasmani. JUARA: Jurnal Olahraga, 2(2), 143-150.

WALUYO, S. (2011). HUBUNGAN MOTIVASI OLAHRAGA, MINAT BELAJAR DAN CARA MENGAJAR DI SEKOLAH DENGAN PRESTASI BELAJAR OLAHRAGA SISWA SMP (Doctoral dissertation, Universitas Muhammadiyah Surakarta).

Warburton, DER, Sheel, WA, \& McKenzie, DC (2008). Cardiorespiratory adaptations to training. The Olympic textbook of medicine in sport. USA: Wiley Blackwell. https://doi.org/10.1002/978144430063 5.

Wulandari, B., \& Surjono, H. D. (2013). Pengaruh problem-based learning terhadap hasil belajar ditinjau dari motivasi belajar PLC di SMK. Jurnal Pendidikan Vokasi, 3(2). 